\title{
Rice seeds yield and quality according to fertilization
}

\author{
Edivaldo Sousa Santana, Lisandro da Luz Ramos, Hudson da Costa Feitoza, \\ João Carlos Medeiros, Fabio Mielezrski*
}

Federal University of Piaui, Campus Professora Cinobelina Elvas, Bom Jesus-Pl, Brazil.

*Corresponding author, e-mail: mfabioagro@hotmail.com

\begin{abstract}
To obtain high seed quality, good fertilization practices are essential due to its influence not only on seed yield and weight, but also controlling the development of seedlings anomalies. Therefore, the aim of this study was to evaluate the effects of different forms of fertilization on yield and physiological quality of upland rice seeds. It was used nitrogen fertilization in coverage as urea and foliar fertilization with macro and micronutrients. The treatments consist of various sources and forms of fertilization, in a randomized block design, as follows: covering at tillering with $\mathrm{N}$ at $34 \mathrm{~kg} \mathrm{ha}^{-1}$; covering at floral primordium with $\mathrm{N}$ at $34 \mathrm{~kg} \mathrm{ha}^{-1}$; foliar fertilization at tillering; foliar fertilization in floral primordium; covering with $\mathrm{N}$ at $34 \mathrm{~kg} \mathrm{ha}^{-1}$ in tillering and foliar fertilization in floral primordium; only basic fertilization and treatment without fertilization. The results showed that the application of nitrogen fertilizer with urea, at tillering and floral primordium at $34 \mathrm{~kg} \mathrm{ha}^{-1}$ of $\mathrm{N}$ increased the production of rice seeds. In addition, coverage with urea and foliar fertilization containing macro and micronutrients increased rice seeds yield and physiological quality.
\end{abstract}

Keywords: soil fertility, Oryza sativa L., seed physiological potential

\section{Resposta de tipos de adubação na produtividade e qualidade de sementes de arroz}

\section{Resumo}

Para obtenção de sementes de alta qualidade, boas práticas de adubação são imprescindíveis. Principalmente, por influenciar não somente na produção e o peso de grãos, como controle de anomalias no desenvolvimento das plântulas. Portanto, objetivou-se avaliar os efeitos de diferentes formas de adubação na produtividade e qualidade fisiológica de sementes de arroz de sequeiro. Utilizou-se adubação em cobertura com nitrogênio na forma de ureia e macro e micronutrientes foliar. Os tratamentos consistiram de fontes e formas de adubação, num delineamento em blocos casualizados, sendo: adubação de cobertura no perfilhamento com N em 34 kg ha-1; adubação de cobertura no primórdio floral com N em $34 \mathrm{~kg}$ ha-1; adubação foliar no perfilhamento; adubação foliar no estádio de primórdio floral; adubação de cobertura com N em 34 kg ha-1 no perfilhamento e adubação foliar no primórdio floral; somente adubação de base e controle sem adubação. Os resultados mostraram que a aplicação da adubação nitrogenada com ureia, no perfilhamento e primórdio floral na dose de $34 \mathrm{~kg}$ ha-1 aumentou a produção de sementes de arroz. Além disso, as adubações de cobertura com ureia e adubo foliar contendo macro e micronutrientes, aumentaram a produtividade e a qualidade fisiológica de sementes de arroz.

Palavras chave: fertilidade do solo, Oryza sativa L., potencial fisiológico de sementes 


\section{Introduction}

The Cerrado biome region, which includes many agricultural frontiers in the northeast of Brazil, present an increase in land use for agriculture, being highlighted as an important agricultural region for the country. In this region, it is possible to observe the plan topography; deep soils and favorable climate for the cultivation of major grain crops and fibers, enabling regional development (Borgui et al., 2014).

The rice (Oryza sativa L.) is one of the main cereal grown in Brazil, highlighting the country's southern state as the largest producer. According to Conab data (2015), Brazil cultivated during the 2014/15 crop year, 2.353 million of hectares with rice, being $80 \%$ of irrigated rice (Breseghello et al., 2011; IBGE, 2014), with an average yield of $7,000 \mathrm{~kg} \mathrm{ha}^{-1}$, compared with quite low $1,800 \mathrm{~kg}$ $\mathrm{ha}^{-1}$ in upland rice area.

The decreases in upland rice area have a variety of causes, including strong competition from irrigated rice from in the south in terms of price and quality, lower risk by substitution and higher-revenue crops (Ferreira et al., 2010), climatic variability (Heinemann et al., 2015), and low soil fertility in upland rice areas (Fageria ef al., 2003). Especially in soils with low contents of organic matter, there is a low availability of nitrogen to the plant.

The amount, period of application and coverage application of nitrogen in rice could increase seeds quality, especially increasing protein content, which is important for the embryo development (Zucareli et al., 2012). The rice plant demands nutrients which should be readily available, not limiting the crop yield. After potassium, nitrogen is the nutrient that the rice plant accumulates in larger amounts (Kischel et al., 2011).

The recommendation of nitrogen fertilizations in cover aiming to increase its efficiency has become routine practice in the fertilization management of the rice crop. However, this nutrient supplementation can occur later, with the main function to improve the protein level rather than the yield (Nascente et al., 2011). A major source of nitrogen used in rice cultivation in coverage is urea and its application is perform on the soil or straw (Pereira et al., 2009).
The need to increase the production of rice seeds has led growers to seek alternatives to improve seed quality. Accordingly, the foliar fertilization is efficient and provides nutrients to plants. Studies on the effects of leaf fertilization with different nutrients combinations in the mixture have shown promising results (Toader et al., 2012). However, there are few researches with this type of fertilization during the plant vegetative stage (Biscaro et al., 2011).

Therefore, more research is needed to measure the effects of forms and times of covering application on rice and seeds yield and quality, especially regarding seed quality. According to Fageria \& Barbosa (2001), the availability of nitrogen for the plant will reflect on rice yield components on seeds physiological parameters (germination and vigor). Moreover, nitrogen uptake by plants can affect the absorption of other nutrients (Cantarella, 2007) in particular the metal micronutrients (Wilkinson et al., 2000). Thus, the aim of this research was to understand the effects of coverage with nitrogen and macro and micronutrients leaf fertilization on yield and physiological quality of upland rice seeds.

\section{Material and methods}

The study was conducted in the experimental area at The Federal University of Piaui - UFPI, Campus Professor Cinobelina Elvas, in Bom Jesus, Piaui Brazil. The experiment location

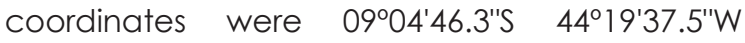
with average altitude of $282 \mathrm{~m}$. The climate, according to Köppen classification is the Aw type, characterized by being warm and humid with an average temperature between 23 and $24^{\circ} \mathrm{C}$. It shows average annual rainfall around $1,100 \mathrm{~mm}$, with rainfall concentrated in the period from November to March (Jacomine, 1986). It was collected the climatic data of Bom Jesus (rainfall, temperature and relative humidity) during the execution of the experiment as shown in Figure 1.

The soil is classified as a Yellow latosol (Latossolo Amarelo) (Embrapa, 2013), with sandy loam texture. The following results were observed after the soil analysis from $0-0.20 \mathrm{~m}: \mathrm{P}=16.6 \mathrm{mg}$ $\mathrm{dm}^{-3} ; \mathrm{K}=0.18 \mathrm{cmol}_{\mathrm{c}} \mathrm{dm}^{-3} ; \mathrm{S}=5.9 \mathrm{mg} \mathrm{dm}^{-3} ; \mathrm{Ca}=$ $1.34 \mathrm{cmol}_{\mathrm{c}} \mathrm{dm}^{-3} ; \mathrm{Mg}=0.19 \mathrm{cmol}_{\mathrm{c}} \mathrm{dm}^{-3} ; \mathrm{Al}=0.1$ 
$\mathrm{cmol}_{\mathrm{c}} \mathrm{dm}^{-3} ; \mathrm{H}+\mathrm{Al}=1.94 \mathrm{cmol}_{\mathrm{c}} \mathrm{dm}^{-3} ; \mathrm{SB}$ (sum of exchangeable bases) $=1.71 \mathrm{cmol}_{\mathrm{c}} \mathrm{dm}^{-3} ; \mathrm{V}$ (base saturation ratio) $=46.09 \% ; \mathrm{m}$ (aluminum saturation index) $=2.7 \% ; \mathrm{Fe}=346.3 \mathrm{mg} \mathrm{dm}^{-3} ; \mathrm{Mn}=48.01 \mathrm{mg}$ $\mathrm{dm}^{-3} ; \mathrm{Co}=0.29 \mathrm{mg} \mathrm{dm}^{-3}$ and $\mathrm{Zn}=1.27 \mathrm{mg} \mathrm{dm}^{-3}$.
For the calculation of lime requirement, the base saturation method was used, aiming a saturation of $50 \%$. The correction was carried out two months before sowing, with lime (PRNT $=88 \%$, $\mathrm{CaO}=31.5 \%$ and $\mathrm{MgO}=17.5 \%$ ) .

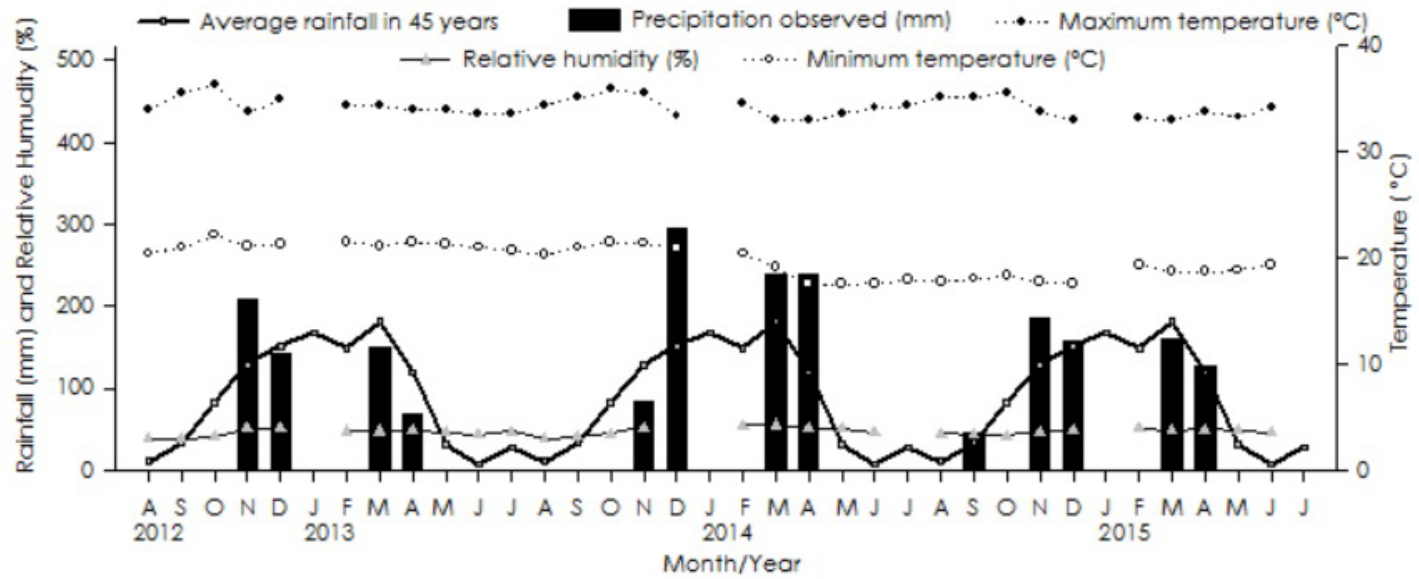

Figure 1. Average temperature data $\left({ }^{\circ} \mathrm{C}\right)$, average relative humidity $(\%)$ and precipitation total (mm) during the experiment period.

The soil preparation was realized using two harrowing of 70 centimeters. The seeds were sowed with $0.5 \mathrm{~m}$ between rows at a depth of $0.05 \mathrm{~m}$. To calculate the amount of seeds used, the germination percentage of $87 \%$ was used, attempting to achieve uniformity and stand by

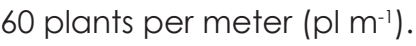

It was performed based fertilization according to soil analysis. At the time of sowing it was applied $182.5 \mathrm{~kg} \mathrm{ha}^{-1}$ of the NPK formula (1: 4: 8), for treatments with based fertilization. When the plants reached the V4 stage (early tillering) and beginning the panicle stage, were performed urea applications $(70 \mathrm{~kg} \mathrm{ha}$ 1) and foliar fertilization at a dose of $2000 \mathrm{ml}$ of the commercial product per hectare. The application was performed manually with a backpack sprayer using water volume of 200 liters per hectare with spray nozzle D20. It was used the following concentration for foliar fertilization: nitrogen (106 $\mathrm{g} \mathrm{ha}^{-1}$ ), phosphorus (170.4 $\mathrm{g} \mathrm{ha}^{-1}$ ), potassium (170.4 $\left.\mathrm{g} \mathrm{ha}^{-1}\right)$, magnesium (21.3 $\mathrm{g} \mathrm{ha}$ 1) and sulfur (25.56 $\left.\mathrm{g} \mathrm{ha}^{-1}\right)$ with the micronutrient boron (10.65 $\left.\mathrm{g} \mathrm{ha}^{-1}\right)$, copper $\left(4.26 \mathrm{~g} \mathrm{ha}^{-1}\right)$, iron (1.06 $\left.\mathrm{g} \mathrm{ha}^{-1}\right)$, manganese ( $\left.10.65 \mathrm{~g} \mathrm{ha}^{-1}\right)$, molybdenum (1.06 $\left.\mathrm{g} \mathrm{ha}^{-1}\right)$ and zinc $\left(21.3 \mathrm{~g} \mathrm{ha}^{-1}\right)$.

The rice cultivar used in the experiment was BRS Sertaneja. The cultivar present an early cycle, adapted to Piaui State and has characteristics of moderate tillering, medium size and median lodging resistance (Breseghello et al. 2006). The experiment was conducted in the field in a randomized blocks design with seven treatments and four repetitions. Each plot consisted of four rows of $3 \mathrm{~m}$ in length, not considering the two sided lines and $0.5 \mathrm{~m}$ at the end - border, so that the useful area of each plot was $2 \mathrm{~m}^{2}$.

Treatments included different stages of covering and manure as fertilizers sources, as follows: covering at the beginning of tillering with nitrogen at $34 \mathrm{~kg} \mathrm{ha}^{-1}$ (T1); covering at the floral primordium stage with $\mathrm{N}$ at $34 \mathrm{~kg} \mathrm{ha}^{-1}$ (T2); foliar fertilization with macro and micronutrients in the early tillering (T3); foliar fertilization with macro and micronutrients in floral primordium stage (T4); covering with $\mathrm{N}$ at $34 \mathrm{~kg} \mathrm{ha}^{-1}$ at the beginning of tillering and foliar fertilization with macro and micronutrients in floral primordium stage (T5); only basic fertilization (T6); control without fertilization (T7).

The plant growth evaluations were performed in the physiological maturity stage in 5 plants selected randomly in each plot. The following variables were evaluated: a) plant height: carried out from the base of the stem until to the apical meristem, b) number of leaves: performed by counting the fully expanded leaves, c) number of tillers: performed by manual counting. 
Also, it was evaluated yield components, determining: a) number of grains per panicle: expressed by the ratio between the total number of grains and the total number of collected panicles. b) panicle length: with the aid of a graduated rule, measuring all of the useful area of panicles. c) seed yield: expressed by the total weight of seeds in the plot where it was estimated the crop yield by correcting the weight to $13 \%$ of moisture, expressing the results in $\mathrm{kg} \mathrm{ha}^{-1}$. d) thousand seed weight: separating eight repetitions of 100 seeds and using the formula described by Brasil (2009).

In seeds with moisture content of $13 \%$, seed physiological quality evaluations were carried out, through the following tests: a) germination test, according to the methodology described in the rules for seed analysis (Brasil, 2009), b) first count of germination: percentage of normal seedlings on the fifth day after the test installation (Brasil, 2009). c) seedling length as described in Nakagawa (1999). d) electrical conductivity, as Krzyzanowski et al. (1999), expressing the results in us $\mathrm{cm}^{-1} \mathrm{~g}^{-1}$.

The variance analysis was carried out using the R program (version 3.2.5) and the results submitted to average comparison by Tukey's test at $5 \%$ of probability.

\section{Results and Discussion}

According to data analysis, significant differences were observed between treatments (Table 1 and 2), except for panicle length (PL), coleoptile length $(\mathrm{CL})$ and radicle length $(\mathrm{RL})$.

Table 1. Summary of the analysis of variance for number of tillers (NT), number of leaves (NL), plant height $(H)$, panicle length (PL), number of seeds per panicle (NSP), thousand seed weight (TSW) and yield (P).

\begin{tabular}{|c|c|c|c|c|c|c|c|c|}
\hline \multirow{2}{*}{ FV } & \multirow{2}{*}{ DF } & \multicolumn{7}{|c|}{ MS } \\
\hline & & NT & $\mathrm{NL}$ & $\mathrm{H}$ & $\mathrm{PL}$ & NSP & TSW & $Y$ \\
\hline Treatments & 6 & $2.01^{* *}$ & $79.77^{* *}$ & $467.11^{* *}$ & $15.06 \mathrm{~ns}$ & $3671.87^{* *}$ & $0.05^{* *}$ & $6029637.0^{* *}$ \\
\hline Blocks & 3 & $0.07 \mathrm{~ns}$ & $4.65 \mathrm{~ns}$ & $20.68 n s$ & $21.15 \mathrm{~ns}$ & 74.10ns & $0.008 \mathrm{~ns}$ & $395494.6 \mathrm{~ns}$ \\
\hline Error & 17 & 0.29 & 6.92 & 13.41 & 6.60 & 156.45 & 0.011 & 118846.2 \\
\hline Total & 26 & & & & & & & \\
\hline
\end{tabular}

Table 2. Summary of the analysis of variance for the first count (FC), germination (G), electrical conductivity(EC), coleoptile length $(\mathrm{CL})$ and radicle length (RL).

\begin{tabular}{ccccccc}
\hline \multirow{2}{*}{ VF } & DF & \multicolumn{5}{c}{ MS } \\
\cline { 3 - 7 } & & $\mathrm{FC}$ & $\mathrm{G}$ & $\mathrm{EC}$ & $\mathrm{CL}$ & $\mathrm{RL}$ \\
\hline Treatments & 6 & $178.67^{* *}$ & $188.00^{* *}$ & $12.50^{* *}$ & $0.1232 \mathrm{~ns}$ & $0.5633 \mathrm{~ns}$ \\
Error & 20 & 18.03 & 18.63 & 1.48 & 0.048 & 0.3882 \\
\hline Total & 26 & \multicolumn{5}{c}{} \\
\hline FV= Source of variation; $\mathrm{DF}=$ degrees of freedom; $M S=$ mean square; ns= no significant,** significant at $1 \%$ of probability by F test
\end{tabular}

For NT and NL variables, the results indicated that only the treatment without fertilization (control) presented differences when compared to other treatments (Table 3). The application on covering did not resulted in differences, when compared with the treatment with only base fertilization. These results clearly demonstrate the importance of basic fertilization for upland rice crop, which provided uniform plant growth.

The nutritional stress in rice seedlings after the exhaustion of seed reserves throughout cycle changed the whole plant development.

For the variable plant height, the results showed that the treatments T1, T2, T3 and T5 were statistically different $(p \leq 0,05)$ than the other treatments. It is shown that application with $\mathrm{N}$ and foliar fertilization at the beginning of tillering can lead to a better development of rice plants.

Supplementation with $\mathrm{N}$ in coverage is an essential practice in the management of rice (Sun et al., 2012), studying rice development and yield. The choose of the right dose to be applied has been the subject of many studies, not only for economic reasons but also for environmental issues (Karin et al., 2014).

For the NSP variable, the results showed that the treatments $\mathrm{T} 1, \mathrm{~T} 2$ and $\mathrm{T} 5$ were statistically different $(p \leq 0,05)$ when compared to others, however, for the TSW, treatments T3, T4, T5, T6 and T7 were higher than Tland T2 treatments. It is observed that the application of $\mathrm{N}$ by urea 
allowed the development of a larger NSP, which possibly influenced the TSW reduction.

For yield, the results showed that the treatments $\mathrm{T} 1, \mathrm{~T} 2$ and $\mathrm{T} 5$ were statistically different $(p \leq 0,05)$ than the other treatments. In general, the use of urea indicated better results.

Table 3. Means valuesfornumberoftillers (NT), numberofleaves (NL), plantheight(H), numberofseedsperpanicle (NSP), thousandseedweight(TSW), yield (Y) incoveredapplication withureaandfoliarfertilizationinuplandrice, Bom Jesus, Piaui, Brazil.

\begin{tabular}{ccccccc}
\hline Treatments & NT & NL & H & NSP & TSW & Y \\
\hline T1 & & & & & \\
T2 & $3.85 a$ & $23.0 \mathrm{a}$ & $55.87 \mathrm{ab}$ & $172.34 \mathrm{ab}$ & $27.55 \mathrm{~b}$ & $5042.0 \mathrm{ab}$ \\
T3 & $2.85 \mathrm{a}$ & $22.0 \mathrm{a}$ & $51.75 \mathrm{ab}$ & $144.50 \mathrm{bc}$ & $30.20 \mathrm{ab}$ & $4185.0 \mathrm{c}$ \\
T4 & $3.15 \mathrm{a}$ & $22.6 \mathrm{a}$ & $51.30 \mathrm{~b}$ & $154.75 \mathrm{bc}$ & $30.48 \mathrm{a}$ & $4505.0 \mathrm{bc}$ \\
T5 & $3.10 \mathrm{a}$ & $23.4 \mathrm{a}$ & $60.15 \mathrm{a}$ & $168.25 \mathrm{ab}$ & $29.92 \mathrm{ab}$ & $5085.0 \mathrm{ab}$ \\
T6 & $2.75 \mathrm{a}$ & $21.1 \mathrm{a}$ & $51.45 \mathrm{~b}$ & $130.25 \mathrm{c}$ & $29.63 \mathrm{ab}$ & $3998.7 \mathrm{c}$ \\
T7 & $1.15 \mathrm{~b}$ & $10.9 \mathrm{~b}$ & $27.50 \mathrm{c}$ & $98.50 \mathrm{~d}$ & $29.33 \mathrm{ab}$ & $1762.5 \mathrm{~d}$ \\
\hline CV (\%) & 19.95 & 12.62 & 7.22 & 8.3 & 3.6 & 8.09 \\
\hline
\end{tabular}

$\mathrm{Tl}=$ Covering with urea at tillering; $\mathrm{T2}$ = Covering with urea at floral primordium; $\mathrm{T3}=$ Foliar at tillering; $\mathrm{T} 4$ = Foliar - floral primordium; $\mathrm{T} 5$ = Urea at tillering+floral primordium; $T 6$ = Basic fertilization; $T 7$ Control-without fertilizer; C.V.\%: coefficient of variation ; 'means followed by the same letter in the column do not differ by Tukey's test ( $p<0,05)$.

These findings may be related to the longer period that the plants remain photosynthetically active during the seed filling, especially when the application of $\mathrm{N}$ occurred in the floral primordium, favoring the seeds formation. The high $\mathrm{N}$ content in vegetative tissue, particularly leaves and stems, is advantageous, particularly during the seed filling stage, as it can extend the higher photosynthetic rates period, providing assimilates and additional reserve to compensate any loss during translocation (Qin et al., 2013).

The application of nitrogen can stimulate the increasing of yield components and rice grains yield (Mingotte et al., 2013). Barreto et al., (2012), studied nitrogen doses and application times. The authors observed that the evaluated cultivars responded to increasing doses and the period of application of $\mathrm{N}$, highlighting 'BRS Primavera' and 'BRS Sertaneja' as the most productive when doses of $\mathrm{N}$ were distributed $50 \%$ at sowing and $50 \%$ at tillering, while BRS Monarca presented the better response to nitrogen fertilization when all the $\mathrm{N}$ was applied at tillering. For nitrogen, the recommendation is necessary to define the use of appropriate application rates and times to maximize the economic returns with the application of nitrogen and minimize the risk of environmental pollution, especially in groundwater (Boldieri et al., 2010).

The application of urea at the beginning of tillering with foliar fertilization in floral primordium (T5) also resulted in highest productivity. The use of foliar fertilization presents as an excellent choice to achieve higher yields, using as additional alternative to provide nutrients to plants. Foliar spraying of fertilizers not only increases crop yields but also reduces the amount of fertilizer applied to soil (Bhuyan et al., 2012). The application of foliar fertilizers could be important to supplement the soil application of fertilizers, which often are not readily available to small growers. Other benefits of the foliar spraying use include the relatively small amount required and the ease of transportation to the field (Jemo et al., 2015).

Although the productivity results do not show significant differences for foliar fertilization applied at the beginning of tillering and floral primordium, foliar fertilization showed positive effects on productivity in different crops (Toader et al., 2012; Soratto et al., 2011; Jemo et al., 2015). The application of $P$ and $N$ foliar improved the productivity of maize (Jemo et al., 2015). For the corn crop, foliar fertilization has efficient response, increased production and balanced nutrition for fertilization systems based on the application of soil fertilizer complex $\mathrm{N}$ and $\mathrm{P}$ and on their interaction with foliar fertilization. However, the exclusive foliar fertilization does not provide significant increases on yield, which justifies its secondary role in relation to the mineral complex and balanced fertilization with $\mathrm{N}$ and $\mathrm{P}$ 
applied to the soil (Toader et al., 2012). In bean crop the absence of nitrogen fertilization on coverage and the application of $\mathrm{N}$ by leaf in the reproductive stage increased the weight and size of grains, grain yield and protein content of bean grains (Soratto et al., 2011). In Table 4 the results of first count (FC) showed that the treatments $T 3, T 4, T 5$ and $T 7$ were statistically different $(p \leq$ $0,05)$ than other treatments, the same observed for $G$. It is observed that the application of foliar fertilizer enabled the production of seeds with better physiological quality. Probably the application of foliar fertilizer with macro and micronutrients provided better development and seed formation, thus contributing to the higher percentage of germination. Foliar fertilization is a common practice for additional stimulation and correction nutrition for plant (Oprică et al., 2011).

Treatment with foliar fertilization possibly presented efficiency in plant uptake, especially on floral primordium stage, enabling better seed development, which was observed in high TSW treatments with foliar fertilization. The nutritional requirement for most species becomes more intense at the beginning of the reproductive stage, being more critical during the seed formation, when considerable amounts of nutrients are translocated mainly $\mathrm{P}$ and $\mathrm{N}$ (Carvalho \& Nakagawa, 2012).

The control without fertilization (T7) resulted in interesting results, with small seed production, allowing greater translocation of nutrients to the plant seeds, being expressed in highest percentage of germination.

Table 4. Mean values of first count (FC), germination percentage (G), electrical conductivity (EC), coleoptile length $(\mathrm{CL})$ and radicle length $(\mathrm{RL})$ in covered application with urea and foliar fertilization in upland rice, Bom Jesus, Piaui, Brazil.

\begin{tabular}{|c|c|c|c|c|c|}
\hline Treatments & FC & G & EC & $\mathrm{CL}$ & RL \\
\hline & \multicolumn{2}{|c|}{------ \% ------- } & us $\mathrm{cm}^{-1} \cdot \mathrm{g}^{-1}$ & \multicolumn{2}{|c|}{------ cm ------ } \\
\hline $\mathrm{Tl}$ & $58 c$ & $73 b$ & 18.7ab & $1.33 a$ & $3.35 a$ \\
\hline $\mathrm{T} 2$ & $64 \mathrm{bc}$ & $78 b$ & $19.0 \mathrm{a}$ & $1.21 \mathrm{a}$ & $3.16 a$ \\
\hline T3 & $75 a$ & $89 a$ & $15.5 \mathrm{c}$ & $0.91 a$ & $3.31 a$ \\
\hline $\mathrm{T} 4$ & $78 a$ & $92 a$ & $15.5 c$ & $1.20 \mathrm{a}$ & $3.52 a$ \\
\hline T5 & $69 a b$ & 83.0ab & $14.0 \mathrm{c}$ & $0.88 a$ & $3.27 a$ \\
\hline T6 & $65 b c$ & $78.0 b$ & $16.0 \mathrm{bc}$ & $0.93 a$ & $2.36 a$ \\
\hline $\mathrm{T} 7$ & $73 a b$ & $91 a$ & $15.5 \mathrm{c}$ & $0.92 a$ & $3.26 a$ \\
\hline $\mathrm{CV}(\%)$ & 6.16 & 5.17 & 7.51 & 20.87 & 19.64 \\
\hline
\end{tabular}

It was observed that for electrical conductivity (EC), $\mathrm{T} 1$ and $\mathrm{T} 2$ treatments showed better results than other treatments. The $\mathrm{N}$ may have contributed to the increased protein content in the seed, allowing greater structure for the membrane system and consequently reducing the ions leaching. Soratto et al. (2011) found that for the bean crop, the application of $\mathrm{N}$ in cover (45 or $90 \mathrm{~kg} \mathrm{ha}^{-1}$ ) resulted in higher protein content in the seeds, both in the absence of foliar application or on soil (R5 or R7). The beneficial effect of $\mathrm{N}$ application was also observed in corn at a dose of $40 \mathrm{~kg} \mathrm{~N} \mathrm{ha}^{-1}$, with the application in the growing stage and $80 \mathrm{~kg}$ $\mathrm{N} \mathrm{ha}^{-1}$ in the reproductive stage have provided less leaching electrolyte, resulting in lower values for electrical conductivity and, consequently, increased vigor of seeds (Zucareli et al, 2012).
For the variables coleoptile length $(\mathrm{CL})$ and radicle length (CR), the results showed no differences between treatments.

In general, it is observed that the application of nitrogen (urea using as source) in the stages of tillering and floral primordium were positive for the crop yield components. However, foliar fertilization also during tillering and floral primordium reflected in higher seed physiological quality (germination and vigor) and physical quality (thousand seed weight). This information is important for seed producers, as present fertilization management alternatives in rice to achieve seeds high yield and quality.

\section{Conclusion}

The application of nitrogen fertilization using urea as source at the beginning of tillering and floral primordium at a dose $34 \mathrm{~kg} \mathrm{ha}^{-1}$ of $\mathrm{N}$ 
increases the upland rice seeds yield.

Foliar fertilization on coverage with macro and micronutrients increase upland rice seeds yield and physiological quality.

\section{References}

Barreto, J.H.B., Soares, I., Pereira, J.A., Bezerra, A.M.B., Deus, J.A.L. 2012. Yield Performance of Upland Rice Cultivars at Different Rates and Times of Nitrogen Application. Revista Brasileira de Ciências do Solo 36:475-483.

Biscaro, G.A., Motomyia, A.V.A., Ranzi, R., Vaz, M.A.D., Prado, E.A.F., Silveira, B.L. R. 2011. Desempenho do milho safrinha irrigado submetido a diferentes doses de nitrogênio via solo e foliar. Revista Agrarian 4:10-19.

Boldieri, F.M., Cazetta, D.A., Filho, D.F. 2010. Adubação nitrogenada em cultivares de arroz de terras altas. Revista Ceres 57:421-428.

Borgui, E., Bortolon, L., Avanzi, J.C., Bortolon, E.S.O., Ummus, M.E., Gontijo Neto, M.M., Costa, R.V. 2014. Desafios das novas fronteiras agrícolas de produção de milho e sorgo no Brasil: desafios da região do MATOPIBA. In: Karam, D., Magalhães, P.C. Eficiência nas cadeias produtivas e 0 abastecimento global. Associação Brasileira de Milho e Sorgo, Sete Lagoas, Brazil. p. 263-278.

Brasil. Ministério da Agricultura. Departamento Nacional de Produção Vegetal. 2009. Regras para Análise de Sementes. MAPA/ACS, Brasília, Brazil. 365 p.

Breseghello, F., Morais, O.P., Castro, E.M., Pereira, J.A., Utumi, M.M., Lopes, A.M., Cordeiro, A.C.C., Bassinello, P.Z., Fonseca, J.R., Prabhu, A.S., Peters, V., Soares, A.A., 2006. BRS Sertaneja: Cultivar Precoce de Arroz de Terras Altas. Embrapa, Santo Antônio de Goiás, Brazil. 4p.

Breseghello, F., Morais, O.P., Pinheiro, P.V. 2011. Results of 25 years of upland rice breeding in Brazil. Crop Science 51: 914-923.

Bhuyan, M.H.M., Ferdousi, M.R., labal, M.T. 2012. Foliar Spray of Nitrogen Fertilizer on Raised Bed Increases Yield of Transplanted Aman Rice over Conventional Method. International Scholarly Research Notices: Agronomy 2012:1-8.

Cantarella, H. Nitrogênio. In: Novais, R. F., Alvarez V., V. H., Barros, N. F., Fontes, R. L. F., Cantarutti, R. B., Neves, J. C. L. 2007. 2.ed. Fertilidade do solo, Sociedade Brasileira de Ciência do Solo, Viçosa, Brazil. p. 375-470.

Carvalho, N.M, Nakagawa, J. 2012. Sementes: ciência, tecnologia e produção. Funep, Jaboticabal, Brazil. 590p.
Conab-Companhia Nacional de Abastecimento. Acompanhamento safra brasileira grãos: Safra 2014/15: Sexto Levantamento. 2015. http:// www.conab.gov.br/OlalaCMS/uploads/ arquivos/15_03_11_14_07_48_boletim_graos_ marco_2015.pdf. <Access on 12 mar. 2015>

Embrapa - Empresa Brasileira de Pesquisa Agropecuária. 2013. Sistema brasileiro de classificação de solos. Centro Nacional de Pesquisas de Solos, Rio de Janeiro, Brazil. 353p.

Fageria, N.K., Slaton, N.A., Baligar, V.C. 2003. Nutrient management for improving lowland rice productivity and sustainability. Advances in Agronomy 80: 63-152.

Fageria, N.K.; Barbosa Filho M.P. 2001. Nitrogen use efficiency in lowland rice genotypes. Communications in Soil Science and Plant Analysis 32: 2079-2089.

Ferreira, C.M. 2010. Overcoming technical despotism in the upland rice productive chain. In: Coudel, E., Devautour, H., Soulard, C.T., Hubert, B. Proceedings of the International Symposium Innovation and Sustainable Development in Agriculture and Food, ISDA, Montpellier, France. 9p.

Heinemann, A.B., Perez, C.B., Villegas, J.R., Londono, D.A., Bonilla-Findji, O., Medeiros, J.C., Jarvis, A. 2015. Variation and impact of drought-stress patterns across upland rice target population of environments in Brazil. Journal of Experimental Botany 4:1-12.

Instituto brasileiro de pesquisas geográficas e econômicas - IBGE. 2014. http://www.sira.ibge. gov.br/bda/ <Access on 17 oct. 2016>

Jacomine, P.K.T. $1986 . \quad$ Levantamento exploratório-reconhecimento de solos do estado do Piauí. DRNEMBRAPA - SNLCS / SUDENE, Recife, Brazil. 383p.

Jemo, M., Nwoke, C., Pypers, P., Vanlauwe, B. 2015. Response of maize (Zea mays) to the application of foliar fertilizers in the Sudan and Guinea savanna zone of Nigeria. Journal of Plant Nutrition Soil Science 178: 374-383.

Karin, S.T.A.U, Zhu, Y., Yao, X., Cao, W. 2014. Determination of critical nitrogen dilution curve based on leaf area index in rice. Field Crops Research, 167: 76-85.

Kischel, E., Fidelis, R.R, Santos, M.M., Brandão, D.R., Cancellier, E.L., Nascimento, I.R. 2011 . Efeito do Nitrogênio em genótipos de arroz cultivados em várzea úmida do Estado do Tocantins. Revista Ceres 58: 84-89

Krzyzanowski, F.C., Vieira, R.D., França Neto, J.B. 1999. Vigor de sementes: conceitos e testes. 
ABRATES, Londrina, Brazil. 50p.

Mingotte, F.L.C., Hanashiro, R.K., Filho; D.F. 2013. Response of rice cultivars to nitrogen in upland conditions. Revista Ceres 60: 086-095.

Nascente, A.S., Kluthcouski, J., Rabelo, R.R., Oliveira, P., Cobucci, T., Crusciol, C.A.C. 2011. Produtividade do arroz de terras altas em função do manejo do solo e da época de aplicação de nitrogênio. Pesquisa Agropecuária Tropical, Goiânia 41: 60-65.

Nakagawa, J. 1999. Testes de vigor baseados no desempenho das plântulas. In: Krzyzanowski, F.C. Vieira, R.D., França Neto, J.B. Vigor de sementes: conceitos e testes. ABRATES. Londrina, Brazil. p. 2.1-2.24.

Oprică, I., Sirbu, C., Cioroianu, T., Soare, M., Grigore, A., Marin, N. 2011 . The influence of foliar fertilizer with organic substances on phosphorus content in maize plant. Research Journal of Agricultural Science 43: 150-153.

Pereira, H.S., Leão, A.F., Verginassi, A., Carneiro, M.A.C. 2009. Ammonia volatilization of urea in the out-of-season corn. Revista Brasileira de Ciência do Solo 33:1685-1694.

Qin, J., Impa, J.M., Tanga, Q., Yang, S., Yang, J., Tao, Y., Jagadish, K.S.V. 2013. Integrated nutrient, water and other agronomic options to enhance rice grain yield and $\mathrm{N}$ use efficiency in doubleseason rice crop. Field Crops Research 148:15-23.

R Development Core Team. 2015. R version 3.2.0: A Language and Environment for Statistical Computing. http://www.R-project.org <Access on 8 nov. 2016> Soratto, R.P., Fernandes, A.M., Souza, E.F.C., Schlick, G.D.S. 2011 . Produtividade e qualidade dos grãos de feijão em função da aplicação de nitrogênio em cobertura e via foliar. Revista Brasileira de Ciência do Solo 35: 2019-2028.

Sun, Y., Ma, J., Sun, Y., Xu, H., Yang, Z., Liu, S., Jia, X, Zheng, H. 2012. The effects of different water and nitrogen managements on yield and nitrogen use efficiency in hybrid rice of China. Field Crops Research 127: 85-98.

Toader, C., Mărghitaş, M., Rusu, M., Mihai, M. 2012. Research on alternatives and strategies for foliar fertilization within differentiated fertilization systems for maize crop. Research Journal of Agricultural Science 44: 163-168.

Wilkinson, S.R., Grunes, D.L., Sumner, M.E. 2000. Nutrient interactions in soil and plant nutrition. In: SUMNER, M.E. (Ed.). Handbook of soil science. Boca Raton: CRC Press, New York, USA. p. 89-112.

Zucareli, C., Panoff, B., Portugal, G., Fonseca, I.C.B. 2012. Doses e épocas de aplicação de nitrogênio em cobertura na qualidade fisiológica de sementes de milho doce. Revista Brasileira de Sementes 34: 480-487. 